\title{
Bone Marrow-Derived Mesenchymal Stem Cells Promote Hepatic Regeneration after Partial Hepatectomy in Rats
}

\author{
Dong-Liang Li Xiu-Hua He Shi-An Zhang Jian Fang Feng-Sui Chen \\ Jing-Jing Fan \\ Department of Hepatobiliary Medicine, Fuzhou General Hospital, Fuzhou, China
}

\section{Key Words}

Mesenchymal stem cell · Partial hepatectomy · Liver regeneration

\begin{abstract}
Objectives: Our goal was to study the ability of mesenchymal stem cells (MSCs) to stimulate liver regeneration after partial hepatectomy in rats. Methods: MSCs were isolated from bone marrow and cultured in vitro. Their characteristics were analyzed by flow cytometry. After $70 \%$ partial hepatectomy, Sprague-Dawley rats were randomly divided into three groups: a control group that was injected with saline, animals that received bone marrow-derived MSCs (BMMSCs) by tail vein injection (the BM-MSC-TV group) and animals that received BM-MSCs by portal vein injection (the BM-MSC-PV group). The injected BM-MSCs were traced by labeling with 4',6-diamidino-2-phenylindole, and cell proliferations were determined by immunohistochemical staining with Ki-67 and 5-bromo-2'-deoxyuridine. Results: After the third passage, the cultured BM-MSCs had a fibroblastlike morphology and expressed high levels of stem cell markers CD29 and CD90. The levels of albumin rose significantly in the BM-MSC-TV and BM-MSC-PV groups compared with the control group. The number of 4',6-diamidino-2-phenyl-
\end{abstract}

\begin{tabular}{ll}
\hline KARGER & $\begin{array}{l}\text { ( } 2013 \text { S. Karger AG, Basel } \\
1015-2008 / 13 / 0805-0228 \$ 38.00 / 0 \quad \text { Karger }\end{array}$ \\
E-Mail karger@karger.com & $\begin{array}{l}\text { This is an Open Access article licensed under the terms } \\
\text { of the Creative Commons Attribution-NonCommercial- } \\
\text { www.karger.com/pat }\end{array}$ \\
& $\begin{array}{l}\text { NoDerivs 3.0 License (www.karger.com/OA-license), appli- } \\
\text { cable to the online version of the article only. Distribution } \\
\text { for non-commercial purposes only. }\end{array}$
\end{tabular}

indole-positive liver cells in the BM-MSC-PV group was significantly higher than in the BM-MSC-TV group. The levels of Ki-67 and 5-bromo-2'-deoxyuridine were significantly higher in the BM-MSC-TV and the BM-MSC-PV groups than in the controls. Conclusion: Taken together, these results indicate that BM-MSC injections enhance liver regeneration after partial hepatectomy in rats.

Copyright ๑ 2013 S. Karger AG, Basel

\section{Introduction}

As a vital organ, the liver has the remarkable feature of regeneration. Hepatitis virus infection, inherited metabolic disease, drug abuse and trauma cause liver injury and can induce hepatic failure. In these situations, liver regeneration is triggered rapidly to restore hepatic function, and hepatic stem cells play an important role in regeneration [1]. Hepatic stem cells in liver tissues have high proliferation potential in vitro and can be induced to differentiate into hepatocytes $[2,3]$. However, hepatocyte proliferation may be inhibited if the injury is too

D.-L.L. and X.-H.H. contributed equally to this work. 
severe [4], and liver regeneration is often compromised after surgery for malignancies $[5,6]$. Poor liver regeneration might result from insufficient hepatic stem cells and/or their late activation. To overcome these limitations, the injection of stem cells in sufficient numbers might be a feasible strategy to restore normal liver functions.

Bone marrow stem cells, including hematopoietic stem cells and bone marrow-derived mesenchymal stem cells (BM-MSCs), are pluripotent and can self-renew. Recently, BM-MSCs have been differentiated into neurons [7], cardiomyocytes [8], endothelial cells [9], chondrocytes [10] and hepatocytes [11]. BM-MSCs can differentiate into hepatocytes in vitro [12] and in vivo [13] and also engraft on injured tissue and recover the function of injured tissue [14, 15]. Furthermore, autologous BM-MSC therapy has shown great promise in enhancing tissue regeneration in a range of acute and chronic disease [16], including liver disease $[17,18]$. Although Kaibori and his colleagues [19] reported that BM-MSCs could stimulate liver regeneration after hepatectomy in mice, BM-MSCs were not characterized in their study. In this study, we clarified the role of BM-MSCs in liver regeneration after partial hepatectomy.

\section{Materials and Methods}

\section{Animals}

Male Sprague-Dawley rats were purchased from SLAC Laboratory Animal Co., Ltd., Shanghai, China, and maintained in isolated ventilated cages under well-controlled conditions at $23^{\circ} \mathrm{C}$, $55-60 \%$ humidity, with ventilation $>1.27 \mathrm{~m}^{3} / \mathrm{h}$ and a 12 -hour light-dark cycle. Animal experiments were performed in compliance with federal Chinese laws and the animal guidelines of Fujian Medical University.

\section{Isolation and Culture of BM-MSCs}

BM-MSCs were harvested from the femurs and tibias of Sprague-Dawley rats (60-80 g) and suspended in complete DMEM/F12 medium (Gibco, USA) supplemented with 10\% fetal bovine serum (PAA Laboratories, Austria), $100 \mathrm{U} / \mathrm{ml}$ penicillin and $100 \mathrm{mg} / \mathrm{l}$ streptomycin. The BM-MSCs were then filtered through a $200-\mu \mathrm{m}$ mesh and suspended in complete DMEM/F12 medium. These cells were cultured at $37^{\circ} \mathrm{C}$ with $5 \% \mathrm{CO}_{2}$, and medium was replaced every 2-3 days. By 7-10 days, when the cell confluence reaches $80-90 \%$, cells were passaged. Subsequently, the cells were split at a 1:2 dilution every 3 days. Cells from the third passage were used in experiments presented.

\section{Flow Cytometry Analysis}

Cells from the third passage were trypsinized and washed twice with PBS. Cells $\left(10^{6} / 100 \mu \mathrm{l}\right)$ were incubated with antibodies against CD29, CD45, CD90 (Biolegend, USA) and CD34 (Santa Cruz, Calif., USA) for $40 \mathrm{~min}$ at room temperature. After incubation, cells were washed with PBS twice and resuspended in $2 \mathrm{ml}$ of PBS for analysis. Coulter flow cytometry was used to analyze the surface markers of the BM-MSCs.

\section{Labeling with 4',6-Diamidino-2-Phenylindole}

When the confluence of BM-MSCs (third passage) reached 6070\%, 4',6-diamidino-2-phenylindole (DAPI; $1 \mu \mathrm{g} / \mathrm{ml}$ ) was added to the medium and cells were cultured for $12 \mathrm{~h}$. After incubation, cells were washed with PBS 6 times and a cell sample was examined by fluorescence microscopy. For identifying DAPI+ BM-MSCs in liver, the liver was harvested on day 9 after surgery and frozen sections were prepared. The DAPI-labeled cells were counted under a fluorescence microscope.

\section{Partial Hepatectomy and Administration of BM-MSCs}

Male Sprague-Dawley rats (180-220 g) were anesthetized with ether. After midline laparotomy, the pedicle of the left lateral and median lobes of the liver were ligated and resected (70\% partial hepatectomy). Suturing of the peritoneum and skin were performed independently. Twenty-four hours after hepatectomy, these rats were divided into three groups: in one group, BM-MSCs $\left(1.5 \times 10^{6}\right)$ were injected into the portal vein (BM-MSC-PV group); in the second group, BM-MSCs $\left(1.5 \times 10^{6}\right)$ were injected into the tail vein (BM-MSC-TV group); in the control group, saline was injected into the tail vein.

\section{Biochemical Analysis of Blood Samples}

On days 3 and 9 after surgery, the blood samples were harvested from the retro-orbital plexus (1-2 ml) and the inferior vena cava (1-5 $\mathrm{ml})$, respectively. The plasma was isolated and alanine transaminase (ALT) and albumin were measured by standard laboratory methods.

\section{Immunohistochemical Analysis of Liver Tissue}

Two hours before sacrifice ( 9 days after surgery), rats were intraperitoneally injected with $50 \mathrm{mg} / \mathrm{kg} 5$-bromo-2'-deoxyuridine (BrdU; Sigma-Aldrich, USA). After being anesthetized by intraperitoneal injection with $10 \%$ chloral hydrate $(0.3 \mathrm{ml} / 100 \mathrm{~g})$, liver tissues were removed and fixed with $10 \%$ formalin for $24 \mathrm{~h}$. Tissue sections 4 - to 7 - $\mu \mathrm{m}$ thick were prepared. After antigen retrieval, endogenous peroxidase was blocked by incubation with $3 \% \mathrm{H}_{2} \mathrm{O}_{2}$ for $10 \mathrm{~min}$. After washing with PBS, slides were blocked with normal goat serum for $30 \mathrm{~min}$. Following the addition of mouse antiBrdU antibody (Zymed Laboratories, USA) diluted 1:600, sections were incubated for $1 \mathrm{~h}$. After washing, slides were incubated with horseradish peroxidase-conjugated goat-anti-mouse antibody for $30 \mathrm{~min}$. Then slides were incubated with DAB solution for 3-10 min and counterstained with hematoxylin. For Ki-67 staining, the staining procedure was the same as the BrdU staining, except that the rabbit anti-rat Ki-67 antibody (Abcam, USA) was used at a 1:50 dilution as primary antibody, and horseradish peroxidaseconjugated goat anti-rabbit antibodies (Gold Bridge, China) were used as the secondary antibody. A clear brown color around the cell nucleus was considered as positive. Ten high-power fields $(\times 400)$ per sample were analyzed.

\section{Statistical Analysis}

Continuous variables were compared by one-way analysis of variance. When a significant difference between groups was apparent, multiple comparisons of means were performed using Stu- 
Fig. 1. Morphology of BM-MSCs. BMMSCs isolated from rats were cultured in vitro and the cell morphology was observed using an inverted microscope. a BM-MSCs 4 days after plating. b BM-MSCs showed a fibroblastic phenotype 3 days after the third passage. $\times 100$.
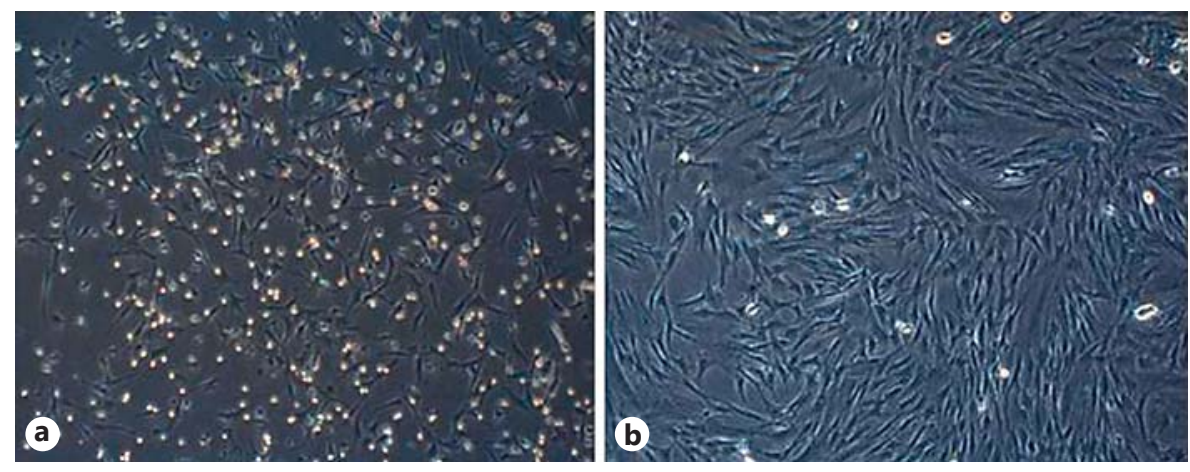

Fig. 2. Characteristics of BM-MSCs. BMMSCs from the third passage were stained with the indicated antibody and analyzed by flow cytometry. a BM-MSCs are shown as a dot plot. The expression levels of CD34 (c), CD45 (d), CD29 (e) and CD90 (f) of BM-MSCs are presented as a histogram. Relative to the isotype antibody (b), the percentage of expression of the indicated markers was defined as the $\mathrm{B}$ region. $\mathrm{FS}=$ Forward scatter; $\mathrm{SS}=$ side scatter; $\mathrm{PE}=$ phycoerythrin.

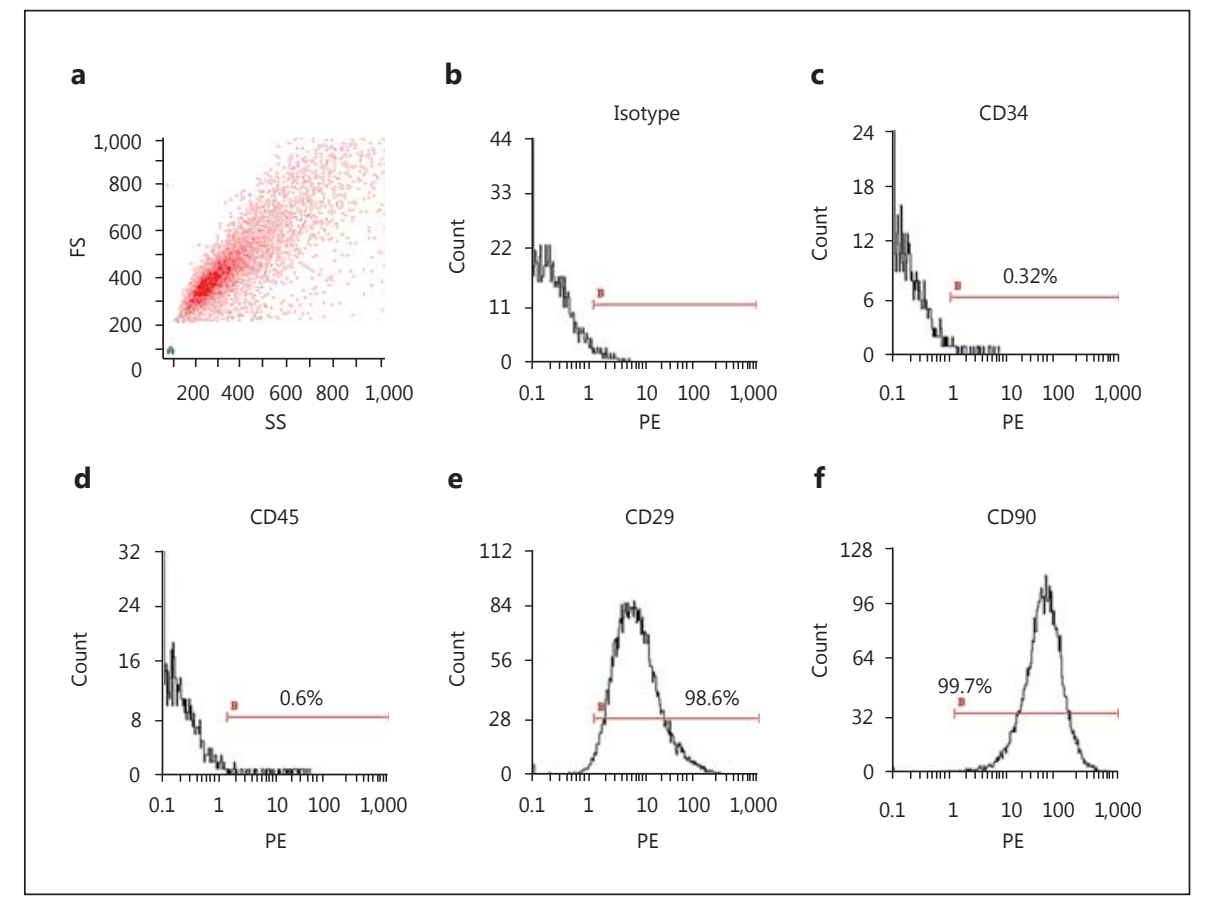

dent-Newman-Keul's test. Data are presented as means \pm standard deviations. Categorical data analyses were performed using Fisher's exact test. All statistical assessments were two-sided and evaluated at the 0.05 level of difference in significance. Statistical analyses were performed using SPSS 15.0 statistics software (SPSS Inc., Chicago, Ill., USA).

\section{Results}

\section{Isolation and Characteristic of Rat BM-MSCs}

Morphologically freshly isolated BM-MSCs were oval in shape (fig. 1a). They attached to culture dishes and grew slowly in the first few days. At the third passage, the BM-MSCs presented a fibroblast-like morphology (fig. 1b). We further assessed the phenotypic characteristics of these cells by flow cytometry. As shown in figure 2 , $98.6 \%$ of the cells expressed the integrin- $\beta$ antigen CD29 and $99.7 \%$ of the cells expressed the stem cell marker CD90, but very few cells expressed the adhesion/stem cell marker CD34 (0.3\%) or CD45 (0.6\%). These phenotypes of culture-expanded BM-MSCs conformed to the criteria for MSCs [20, 21].

\section{Injection of BM-MSCs after Partial Hepatectomy}

To determine the regenerative capabilities of BMMSCs, we injected these cells into a partial hepatectomy 
Fig. 3. Detection of DAPI-labeled BMMSCs in damaged liver. Nine days after hepatectomy, rats were sacrificed and livers were frozen and sectioned. The DAPI-labeled BM-MSCs were observed by fluorescence microscope. $\times 100$.
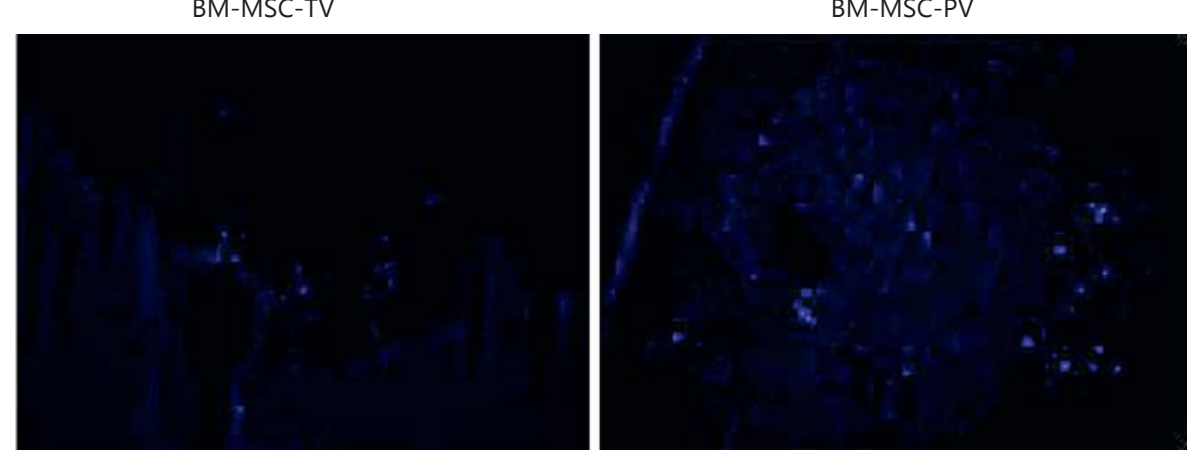

Table 1. Serum levels of ALT and albumin in rats subjected to partial hepatectomy at days 3 and 9 after injection of BM-MSCs

\begin{tabular}{|c|c|c|c|c|c|}
\hline \multirow[t]{2}{*}{ Groups } & \multirow[t]{2}{*}{$\mathrm{n}$} & \multicolumn{2}{|l|}{ Day 3} & \multicolumn{2}{|l|}{ Day 9} \\
\hline & & ALT, U/1 & ALB, g/l & ALT, U/1 & ALB, g/l \\
\hline Saline & 10 & $95.2 \pm 28.3$ & $30.3 \pm 3.6$ & $73.6 \pm 19.1$ & $29.2 \pm 4.9$ \\
\hline BM-MSC-TV & 9 & $105.5 \pm 40.8$ & $24.2 \pm 11.9$ & $53.2 \pm 21.9$ & $35.1 \pm 3.5^{*}$ \\
\hline BM-MSC-PV & 9 & $150.7 \pm 86.8$ & $27.4 \pm 2.0$ & $73.5 \pm 19.0$ & $34.1 \pm 2.6^{*}$ \\
\hline
\end{tabular}

Results are shown as the mean \pm standard deviation. $\mathrm{ALB}=$ Albumin. ${ }^{*} \mathrm{p}<0.05$, significant difference versus the saline group.

rat model. In the BM-MSC-PV animals, 1 rat bled to death and 9 rats survived after the injections. In the BMMSC-TV group, 9 rats survived after injection and only 1 rat had breathing problems that resulted in death. All rats survived saline injection (10/10). Five days after hepatectomy, 3 rats in the saline group $(3 / 10)$ and 1 rat in the BM-MSC-PV group (1/9) had enlarged abdomens. Nine days after the hepatectomies, rats were sacrificed and ascites were examined in those rats with enlarged abdomens. The results showed that 3 rats in the saline group and 1 rat in the BM-MSC-PV group had ascites. No ascites were observed in the BM-MSC-TV group (0/9). There was no significant difference in the incidences of ascites 5 days after hepatectomy among the 3 groups $(\mathrm{p}=0.288)$.

\section{Liver Function after BM-MSC Injection}

Three days after hepatectomy, the levels of ALT were slightly higher in the BM-MSC-PV $(150.7 \pm 86.8 \mathrm{U} / \mathrm{l})$ and BM-MSC-TV $(105.5 \pm 40.8 \mathrm{U} / \mathrm{l})$ groups than in the saline $(95.2 \pm 28.3 \mathrm{U} / \mathrm{l})$ group, whereas the levels of albumin were lower in the BM-MSC-PV $(27.4 \pm 2.0 \mathrm{~g} / \mathrm{l})$ and BMMSC-TV $(24.2 \pm 11.9 \mathrm{~g} / \mathrm{l})$ groups than in the saline con- trol group $(30.3 \pm 3.6 \mathrm{~g} / \mathrm{l})$, but the difference was not statistically significant. Nine days after hepatectomy, the levels of ALT in the BM-MSC-TV $(53.2 \pm 21.9 \mathrm{U} / \mathrm{l})$ and BM-MSC-PV $(73.3 \pm 19.0 \mathrm{U} / \mathrm{l})$ groups decreased towards the levels seen in the saline control group $(73.6 \pm 19.1$ $\mathrm{U} / \mathrm{l})$. However, the levels of albumin were significantly elevated $(\mathrm{p}<0.05)$ in the BM-MSC-injected groups (BMMSC-TV $35.1 \pm 3.5 \mathrm{~g} / \mathrm{l}$, and BM-MSC-PV $34.1 \pm 2.6 \mathrm{~g} / \mathrm{l})$ when compared with the saline control group $(29.2 \pm 4.9$ $\mathrm{g} / \mathrm{l})$. There was no statistically significant difference between the BM-MSC-TV group and the BM-MSC-PV group (table 1).

\section{Tracing of Injected BM-MSCs}

To trace the injected cells, BM-MSCs were labeled with DAPI before injection (fig. 3). Nine days after injection, high levels of DAPI-labeled BM-MSCs were observed in the BM-MSC-PV group $(18.1 \pm 3.4)$ when compared with the BM-MSC-TV group $(7.6 \pm 2 ; \mathrm{p}<0.001)$.

\section{Expression of Ki-67 and DNA Synthesis in Damaged Liver}

To examine the proliferative activity of the injected BM-MSCs, immunohistochemical staining for the proliferation indicator, Ki-67, was performed. As shown in figure 4, 9 days after hepatectomy, many Ki-67+ nuclei were observed in the BM-MSC-injected groups (BM-MSC-TV $103.3 \pm 40.4$ cells, and BM-MSC-PV $95.8 \pm 26.6$ cells), more than in the saline group $(60.2 \pm 35.7$ cells; $\mathrm{p}=0.023)$. To further confirm the proliferation of hepatocytes, we analyzed DNA synthesis by BrdU staining after BM-MSC injection (fig. 5). Nine days after hepatectomy, the levels of BrdU+ cells were higher in the BM-MSC-injected groups (BM-MSC-TV $15.9 \pm 3.0$ cells, and BM-MSC-PV $16.0 \pm 3.3$ cells $)$ than in the saline group $(11.6 \pm 3.7$ cells; $\mathrm{p}=0.01)$. 

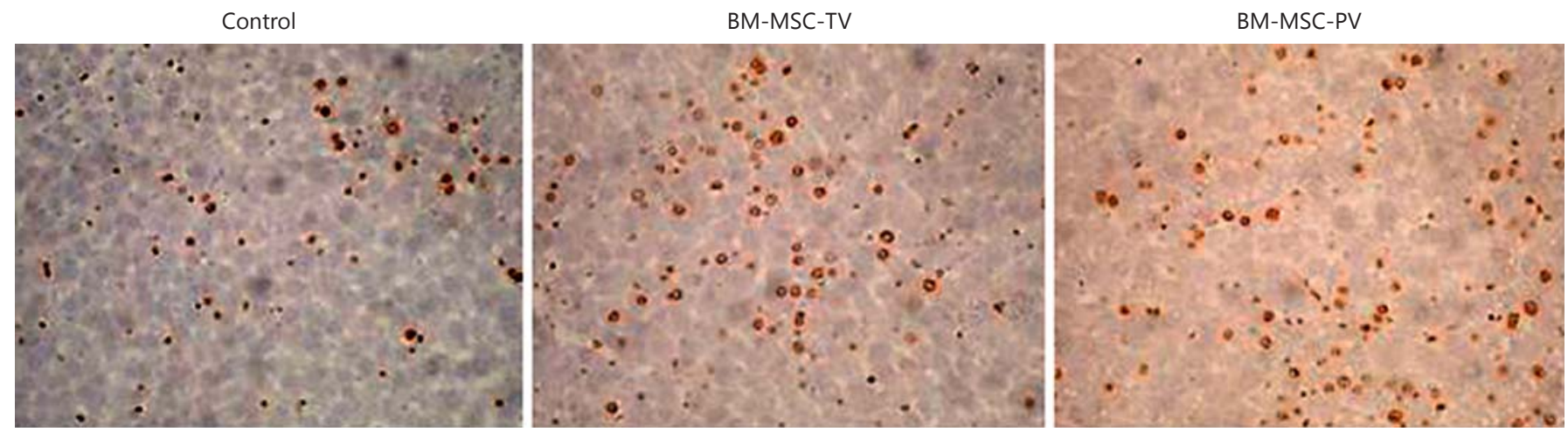

Fig. 4. Expression of Ki-67 in damaged liver. Nine days after hepatectomy, the livers were removed and the expression of Ki-67 was determined by immunohistochemical staining. $\times 400$.
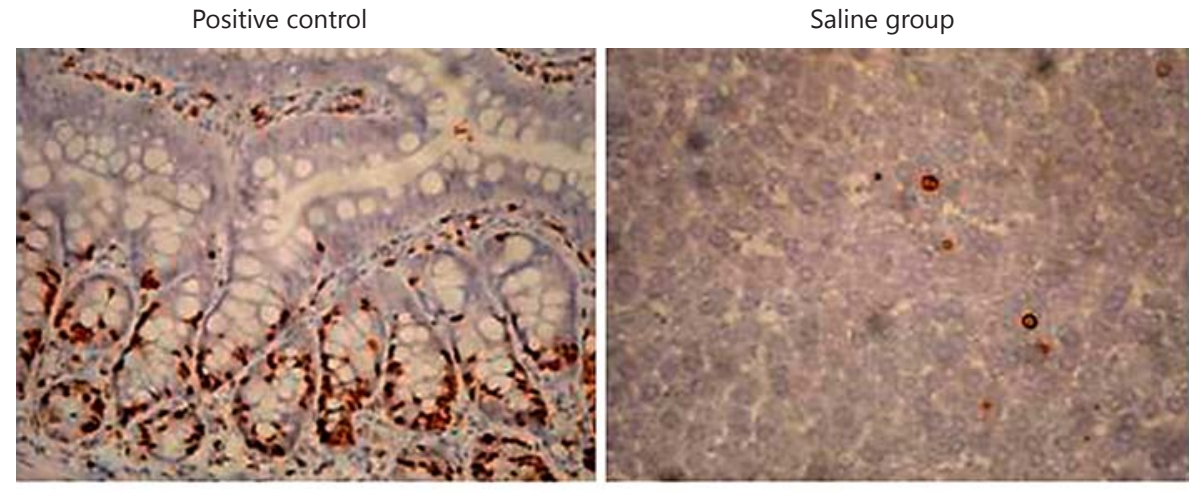

Fig. 5. Effects of BM-MSCs on hepatocyte proliferation. Nine days after hepatectomy, the livers were processed for BrdU levels immunohistochemically to quantify hepatocyte proliferation. Representative micrographs of hepatocyte proliferation in liver tissue are shown. A small intestine sample showing high proliferation was used as a positive control.
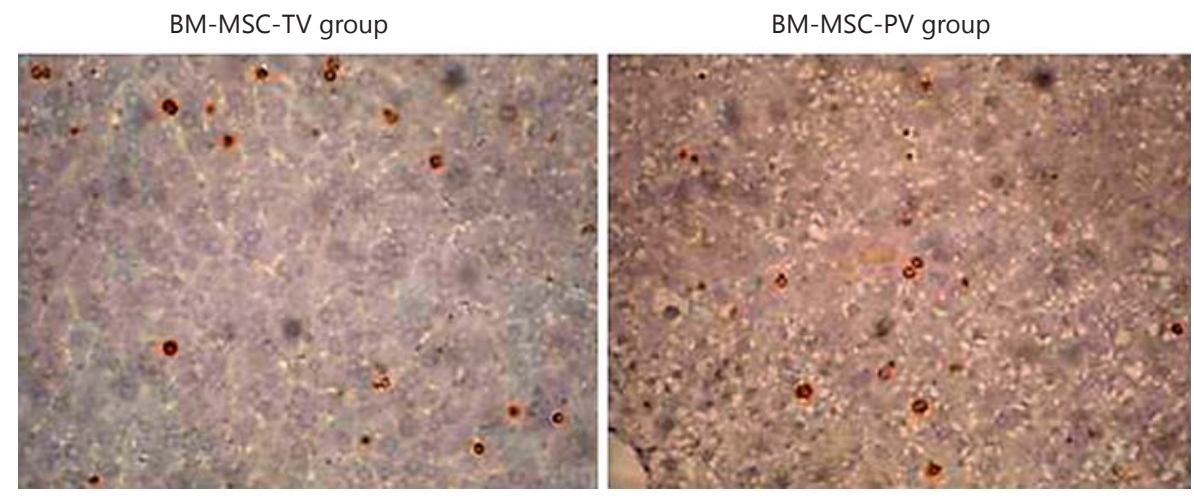

\section{Discussion}

MSCs, the major stem cells in bone marrow, constitute the microenvironment of the bone marrow, regulate hematopoietic function and differentiate into various cells, including hepatocytes $[10,11,22-24]$. BM-MSCs are easily isolated from bone marrow, readily cultured in vitro and can be used for autologous transplantation. Thus, they may be ideal seed cells for the treatment of injured tissue. The use of BM-MSCs is being explored in the fields of regenerative medicine and tissue engineering.

The hepatic microenviroment provides key factors that promote the differentiation of MSCs into hepatocyte-like cells that have the ability to recover normal liver function. 
Arikura and his colleagues [25] immediately injected normal BM-MSCs through the portal vein after $70 \%$ partial hepatectomy of albumin-deficient rats. Four weeks after the injections, the expression of albumin mRNA and protein was seen in the liver of the albumin-deficient rats. Furthermore, albumin was present in serum. While Abdel Azizet et al. [14] isolated CD29+ MSCs from the bone marrow of males and injected them into the tail vein in a female rat fibrosis model, they found that the MSCs could differentiate into hepatocyte-like cells and reduce fibrosis by decreasing the precipitation of collagen. These results support the role of MSCs as a therapeutic agent for liver disease. In contrast, Cantz et al. [26] reported that differentiation of hepatocytes and regeneration were not observed after injection of MSCs. Therefore, the role of MSCs needs to be further clarified for liver disease therapy.

In this study, DAPI-labeled BM-MSCs injected through either the portal vein or tail vein were traced after $70 \%$ hepatectomy in rats. Higher amounts of DAPI+ BM-MSCs were observed in the BM-MSC-PV group than in the BMMSC-TV group, suggesting that the injection route influences the homing of BM-MSCs. However, both portal vein and tail vein injection showed similar effects in enhancing liver regeneration and the recovery of normal liver function. There was no positive correlation between liver regeneration and the amount of homing BM-MSCs. Probably, 9 days was too short to analyze the capacity of homing BM-MSCs to differentiate into hepatocyte-like cells. The other possibility to explain this result is that MSCs could stimulate the proliferation of hepatocytes to promote liver regeneration in the injured liver.

The repopulation efficiency of injected cells after liver injury is another issue. Embryonic stem cell-derived hepatocytes have shown low repopulation efficiency in re- cipient livers [27-29]. These results suggest that using well-differentiated hepatocytes for transplantation still causes some problems. The treatment of BM-MSCs after $70 \%$ hepatectomy might face a similar problem. However, administration of a growth factor or nitric oxide donor, such as insulin-like growth factor 1 [30] and sodium nitroprusside [31], to increase the differentiation and repair ability of BM-MSCs after transplantation might overcome this problem. Therefore, using progenitor cells which could migrate and differentiate into hepatocytes at the liver might be an alternative strategy for the treatment of liver injury.

Hepatocytes play a major role in liver regeneration after partial hepatectomy. Oval cells derived from the liver and bone marrow have been demonstrated to be hepatic stem cells [32-34], can be induced to differentiate into hepatocytes and are responsive to liver toxicity to promote liver regeneration. It has also been suggested that bone marrow cells could differentiate into hepatocytes after severe liver injury. When serious liver injury occurs, bone marrow stem cells quickly migrate to the liver and differentiate into hepatocytes [23]. In this study, the injected BM-MSCs could migrate to the damaged liver and might differentiate into hepatocytes to promote liver regeneration after partial hepatectomy.

In conclusion, we have demonstrated the effect of BMMSCs after partial hepatectomy in rats. Autologous stem cells might provide a promising therapeutic effect on liver regeneration after surgery or liver injury.

\section{Acknowledgement}

This study was supported by the Key project of Fujian Province Science and Technology Plan (2011Y0043).

\section{References}

$>1$ Duncan AW, Dorrell C, Grompe M: Stem cells and liver regeneration. Gastroenterology 2009; 137:466-481.

-2 He ZP, Tan WQ, Tang YF, Zhang HJ, Feng MF: Activation, isolation, identification and in vitro proliferation of oval cells from adult rat livers. Cell Prolif 2004;37:177-187.

$\checkmark 3$ He ZP, Tan WQ, Tang YF, Feng MF: Differentiation of putative hepatic stem cells derived from adult rats into mature hepatocytes in the presence of epidermal growth factor and hepatocyte growth factor. Differentiation 2003;71:281-290.

$\checkmark 4$ Chatzipantelis P, Lazaris AC, Kafiri G, Nonni A, Papadimitriou K, Xiromeritis K, Patsouris ES: CD56 as a useful marker in the regenera- tive process of the histological progression of primary biliary cirrhosis. Eur J Gastroenterol Hepatol 2008;20:837-842.

$\checkmark 5$ Karoui M, Penna C, Amin-Hashem M, Mitry E, Benoist S, Franc B, Rougier P, Nordlinger B: Influence of preoperative chemotherapy on the risk of major hepatectomy for colorectal liver metastases. Ann Surg 2006;243:1-7.

6 Kandutsch S, Klinger M, Hacker S, Wrba F, Gruenberger B, Gruenberger T: Patterns of hepatotoxicity after chemotherapy for colorectal cancer liver metastases. Eur J Surg Oncol 2008;34:1231-1236.

7 Kopen GC, Prockop DJ, Phinney DG: Marrow stromal cells migrate throughout fore- brain and cerebellum, and they differentiate into astrocytes after injection into neonatal mouse brains. Proc Natl Acad Sci USA 1999; 96:10711-10716.

$>8$ Yoon J, Choi SC, Park CY, Choi JH, Kim YI, Shim WJ, Lim DS: Bone marrow-derived side population cells are capable of functional cardiomyogenic differentiation. Mol Cells 2008; 25:216-223.

9 Liu Z, Jiang Y, Hao H, Gupta K, Xu J, Chu L, McFalls E, Zweier J, Verfaillie C, Bache RJ: Endothelial nitric oxide synthase is dynamically expressed during bone marrow stem cell differentiation into endothelial cells. Am J Physiol Heart Circ Physiol 2007;293:H1760H1765. 
$>10 \mathrm{Hu}$ J, Feng K, Liu X, Ma PX: Chondrogenic and osteogenic differentiations of human bone marrow-derived mesenchymal stem cells on a nanofibrous scaffold with designed pore network. Biomaterials 2009;30:50615067.

-11 Chivu M, Dima SO, Stancu CI, Dobrea C, Uscatescu V, Necula LG, Bleotu C, Tanase C, Albulescu R, Ardeleanu C, Popescu I: In vitro hepatic differentiation of human bone marrow mesenchymal stem cells under differential exposure to liver-specific factors. Transl Res 2009;154:122-132.

$\checkmark 12$ Lee KD, Kuo TK, Whang-Peng J, Chung YF, Lin CT, Chou SH, Chen JR, Chen YP, Lee OK: In vitro hepatic differentiation of human mesenchymal stem cells. Hepatology 2004;40: 1275-1284.

13 Fang B, Shi M, Liao L, Yang S, Liu Y, Zhao RC: Systemic infusion of FLK1(+) mesenchymal stem cells ameliorate carbon tetrachlorideinduced liver fibrosis in mice. Transplantation 2004;78:83-88.

-14 Abdel Aziz MT, Atta HM, Mahfouz S, Fouad HH, Roshdy NK, Ahmed HH, Rashed LA, Sabry D, Hassouna AA, Hasan NM: Therapeutic potential of bone marrow-derived mesenchymal stem cells on experimental liver fibrosis. Clin Biochem 2007;40:893-899.

15 Zhao DC, Lei JX, Chen R, Yu WH, Zhang XM, Li SN, Xiang P: Bone marrow-derived mesenchymal stem cells protect against experimental liver fibrosis in rats. World J Gastroenterol 2005;11:3431-3440.

-16 Stutchfield BM, Rashid S, Forbes SJ, Wigmore SJ: Practical barriers to delivering autologous bone marrow stem cell therapy as an adjunct to liver resection. Stem Cells Dev 2010;19: 155-162.

17 Flohr TR, Bonatti H Jr, Brayman KL, et al: The use of stem cells in liver disease. Curr Opin Organ Transplant 2009;14:64-71.

18 Houlihan DD, Newsome PN: Critical review of clinical trials of bone marrow stem cells in liver disease. Gastroenterology 2008; 135 : 438-450.
19 Kaibori M, Adachi Y, Shimo T, Ishizaki M, Matsui K, Tanaka Y, Ohishi M, Araki Y, Okumura T, Nishizawa M, Kwon AH: Stimulation of liver regeneration after hepatectomy in mice by injection of bone marrow mesenchymal stem cells via the portal vein. Transplant Proc 2012;44:1107-1109.

20 Yu J, Cao H, Yang J, Pan Q, Ma J, Li J, Li Y, Li J, Wang Y, Li L: In vivo hepatic differentiation of mesenchymal stem cells from human umbilical cord blood after transplantation into mice with liver injury. Biochem Biophys Res Commun 2012;422:539-545.

21 Lyahyai J, Mediano DR, Ranera B, Sanz A, Remacha AR, Bolea R, Zaragoza P, Rodellar $\mathrm{C}$, Martin-Burriel I: Isolation and characterization of ovine mesenchymal stem cells derived from peripheral blood. BMC Vet Res 2012;8:169.

22 Hayase M, Kitada M, Wakao S, Itokazu Y, Nozaki K, Hashimoto N, Takagi Y, Dezawa M: Committed neural progenitor cells derived from genetically modified bone marrow stromal cells ameliorate deficits in a rat model of stroke. J Cereb Blood Flow Metab 2009;29: 1409-1420.

23 Tokcaer-Keskin Z, Akar AR, Ayaloglu-Butun F, Terzioglu-Kara E, Durdu S, Ozyurda U, Ugur M, Akcali KC: Timing of induction of cardiomyocyte differentiation for in vitro cultured mesenchymal stem cells: a perspective for emergencies. Can J Physiol Pharmacol 2009;87:143-150.

24 Liu JW, Dunoyer-Geindre S, Serre-Beinier V, Mai G, Lambert JF, Fish RJ, Pernod G, Buehler L, Bounameaux H, Kruithof EK: Characterization of endothelial-like cells derived from human mesenchymal stem cells. J Thromb Haemost 2007;5:826-834.

25 Arikura J, Inagaki M, Huiling X, Ozaki A, Onodera K, Ogawa K, Kasai S: Colonization of albumin-producing hepatocytes derived from transplanted F344 rat bone marrow cells in the liver of congenic Nagase's analbuminemic rats. J Hepatol 2004;41:215-221.

-26 Cantz T, Sharma AD, Jochheim-Richter A, Arseniev L, Klein C, Manns MP, Ott M: Reevaluation of bone marrow-derived cells as a source for hepatocyte regeneration. Cell Transplant 2004;13:659-666.
27 Basma H, Soto-Gutiérrez A, Yannam GR, Liu L, Ito R, Yamamoto T, Ellis E, Carson SD, Sato $S$, Chen Y, Muirhead D, Navarro-Alvarez N, Wong RJ, Roy-Chowdhury J, Platt JL, Mercer DF, Miller JD, Strom SC, Kobayashi N, Fox IJ: Differentiation and transplantation of human embryonic stem cell-derived hepatocytes. Gastroenterology 2009;136:990-999.

28 Haridass D, Yuan Q, Becker PD, Cantz T, Iken M, Rothe M, Narain N, Bock M, Nörder M, Legrand N, Wedemeyer H, Weijer K, Spits H, Manns MP, Cai J, Deng H, Di Santo JP, Guzman CA, Ott M: Repopulation efficiencies of adult hepatocytes, fetal liver progenitor cells, and embryonic stem cell-derived hepatic cells in albumin-promoter-enhancer urokinase-type plasminogen activator mice. Am J Pathol 2009;175:1483-1492.

29 Heo J, Factor VM, Uren T, Takahama Y, Lee JS, Major M, Feinstone SM, Thorgeirsson SS: Hepatic precursors derived from murine embryonic stem cells contribute to regeneration of injured liver. Hepatology 2006;44:14781486.

30 Ayatollahi M, Soleimani M, Tabei SZ, Kabir Salmani M: Hepatogenic differentiation of mesenchymal stem cells induced by insulin like growth factor-I. World J Stem Cells 2011; 3:113-121.

31 Ali G, Mohsin S, Khan M, Nasir GA, Shams S, Khan SN, Riazuddin S: Nitric oxide augments mesenchymal stem cell ability to repair liver fibrosis. J Transl Med 2012;10:75.

-32 Haruna Y, Saito K, Spaulding S, Nalesnik MA, Gerber MA: Identification of bipotential progenitor cells in human liver development. Hepatology 1996;23:476-481.

-33 Petersen BE, Bowen WC, Patrene KD, Mars WM, Sullivan AK, Murase N, Boggs SS, Greenberger JS, Goff JP: Bone marrow as a potential source of hepatic oval cells. Science 1999;284:1168-1170

34 Wang X, Foster M, Al-Dhalimy M, Lagasse E, Finegold M, Grompe M: The origin and liver repopulating capacity of murine oval cells. Proc Natl Acad Sci USA 2003;100(suppl 1):11881-11888 